\title{
KEMBALINYA TRADISI: RASIONALITAS DAN ETIKA KOMUNITARIAN ALASDAIR MACINTYRE
}

\author{
Amin Mudzakkir \\ Lembaga Ilmu Pengetahuan Indonesia - LIPI
}

\begin{abstract}
This paper will discuss rationality and ethics in the thought of Alasdair MacIntyre. Like other communitarian thinkers, tradition is the keyword in his thinking. MacIntyre's rationality and ethics are tradition-based rationality and ethics. The return of tradition in the debate of rationality and ethics is a critique of the Enlightenment project which assumes that tradition is irrational. But MacIntyre also disagrees with the post-enlightenment argument with a relativist and perspective tendency. However the rationality and ethics proposed by MacIntyre still has a certain principle of objectivity. Used in contemporary realities, including in Indonesia, Alasdair Macintyre's thought is useful for understanding political identity critically.
\end{abstract}

KEYWORDS: rationality, ethics, traditions, communiatrian, Alasdair Macintyre

ABSTRAK: Tulisan ini akan mendiskusikan rasionalitas dan etika dalam pemikiran Alasdair MacIntyre. Seperti pemikir komunitarian lainnya, tradisi adalah kata kunci dalam pemikirannya. Rasionalitas dan etika MacIntyre adalah rasionalitas dan etika yang berbasis pada tradisi. Kembalinya tradisi dalam perdebatan rasionalitas dan etika merupakan kritik terhadap proyek Pencerahan yang menganggap bahwa tradisi adalah irasional. Akan tetapi MacIntyre juga tidak setuju dengan argumen pasca-Pencerahan yang bertendensi relativis dan perspektivis. Bagaimanapun rasionalitas dan etika yang yang diajukan oleh MacIntyre tetap mempunyai prinsip objektivitas tertentu. Digunakan dalam realitas 
kekinian, termasuk di Indonesia, pemikiran Alasdair Macintyre cukup berguna untuk memahami gejala politik identitas lebih kritis.

KATA-KATA KUNCl: rasionalitas, etika, tradisi, komunitarianisme, Alasdair Macintyre

\section{Pendahuluan}

Cukup mengherankan bahwa di Indonesia tidak berkembang diskusi yang luas tentang komunitarianisme. Sependek pelacakan saya, bahkan tidak ada satu pun buku dalam bahasa Indonesia yang menggunakan kata ini dalam judulnya. Lebih dari itu, istilah komunitarianisme sering dikacaukan dengan komunalisme dan bahkan komunisme. Lalu ketika banyak orang di negeri ini ramai mempromosikan konsep multikulturalisme, debat tentang komunitarianisme tidak kunjung datang juga. Dalam studinya, Gerry van Klinken memang menyebut munculnya politik komunitarian dalam konteks otonomi daerah dan desentralisasi pasca-Soeharto, tetapi amatan dia tertuju secara terbatas pada kebangkitan keraton-keraton lokal. ${ }^{1} \mathrm{Di}$ tempat lain Vedi Hadiz dan Robert Hefner mencoba mengaitkan beberapa gagasan dan aksi politik Indonesia dengan komunitarianisme sebagaimana diperdebatkan dalam filsafat dan teori politik, meskipun analisis awal mereka berangkat dari pembahasan tentang kontras antara demokrasi Barat dan demokrasi berbasis 'Asian values' - secara sinis sering disebut 'illiberal democracy' - yang menjadi kerangka umum dalam buku bunga-rampai suntingan Chua Beng Huat itu. ${ }^{2}$

Komunitarianisme berkembang terutama dalam tradisi filsafat dan teori politik di Amerika Serikat. Muncul pada permulaan dekade 1980-an dan awalnya dikontraskan dengan liberalisme, komunitarianisme

\footnotetext{
1 Gerry van Klinken, "Return of the sultans: the communitarian turn in local politics", dalam Jamie S. Davidson \& David Henley (eds.), The Revival of Tradition in Indonesian Politics: The Deployment of Adat from Colonialism to Indigenism (London \& New York: Routledge, 2007).

2 Chua Beng Huat, Communitarian Politics in Asia (London/New York: Routledge, 2004).
} 
menolak penekanan pada kebebasan individu yang bersifat metafisik dalam paham liberal. Kaum komunitarian mengajukan arti penting komunitas dan tradisi yang terabaikan oleh liberalisme. Secara lebih spesifik, komunitarianisme yang ditokohi oleh Charles Taylor, Alasdair MacIntyre, Michael Walzer, dan Michael Sandel adalah tanggapan terhadap konsepsi keadilan John Rawls dalam A Theory of Justice. ${ }^{3}$ Penolakan kaum komunitarian ini sungguh mendasar, karena mempertanyakan pengertian rasionalitas yang menjadi basis epistemologi liberalisme itu sendiri, juga implikasi praktisnya pada etika. Dalam perkembangannya, komunitarianisme bercabang sedemikian rupa, mulai dari yang cenderung konservatif hingga lebih bernuansa progresif. Hubungannya dengan liberalisme juga berjalan dialogis, sehingga memunculkan arsiran-arsiran tertentu di kedua belah pihak.

Salah satu filsuf komunitarian terkemuka yang sangat berpengaruh pada masa sekarang, khususnya di negeri-negeri berbahasa Inggris, adalah Alasdair MacIntyre. Minatnya luas dan perspektifnya berkembang sedemikian rupa. Setelah bekecimpung sekian lama dalam pengaruh Marxisme, dia kemudian menaruh harapan kepada filsafat Aristotelles dan Thomas Aquinas. Oleh karena itu, belakangan dia menyebut dirinya sebagai penganut Thomisme. Bukunya yang paling fenomenal, After Virtue, ${ }^{4}$ sangat berpengaruh luas, khususnya dalam bidang etika, karena dinilai membangkitkan kembali pemikiran tentang etika keutamaan dari Aristotelles. Setelah itu, MacIntyre menerbitkan Whose Justice? Which Rationality?5, yang merupakan elaborasi lebih lanjut dari buku pertamanya. Pada buku ini MacIntyre secara panjang lebar mengungkapkan pandangannya tentang rasionalitas yang mendasari gagasannya tentang etika.

\footnotetext{
3 John Rawls, A Theory of Justice (Massachusetts: Harvard University Press, 1999 [revised edition]).

4 Alasdair MacIntyre, After Virtue: A Study in Moral Theory (Notre Dame, Indiana: University of Notre Dame Press, 2007 [third edition]).

5 Alasdair MacIntyre, Whose Justice? Which Rationality (Notre Dame, Indiana: University of Notre Dame Press, 1988).
} 
Tulisan kecil ini akan mendiskusikan pemikiran MacIntyre yang berkaitan dengan rasionalitas dan etika. Seperti pemikir kosmopolitan lainnya, tradisi adalah kata kunci dalam pemikirannya. Rasionalitas dan etika MacIntyre adalah rasionalitas dan etika yang berbasis pada tradisi. Kembalinya tradisi dalam perdebatan rasionalitas dan etika merupakan kritik terhadap proyek Pencerahan yang menganggap bahwa tradisi adalah irasional. Akan tetapi, MacIntyre juga tidak setuju dengan argumen pasca-Pencerahan yang bertendensi relativis dan perspektivis. Bagaimana MacIntyre mengatasi baik proyek Pencerahan maupun pascaPencerahan dan mengapa tradisi menjadi penting adalah inti permasalahan yang akan dicoba jawab oleh tulisan ini.

\section{Menyanggah Pasca-Pencerahan, Menyelamatkan Objektivitas Pencerahan}

Tantangan terbaru komunitarianisme justru datang dari pascamodernisme yang oleh MacIntyre disebut pasca-Pencerahan. Berkaitan dengan perdebatan tentang tradisi, kaum pasca-Pencerahan mengajukan argumen yang bersifat relativistik dan perspektivis. Relativisme yang dimaksud adalah pandangan yang menyatakan bahwa etika sebuah tradisi hanyalah valid di dalam tradisi itu sendiri, tidak bisa divalidasi oleh tradisi lain, sehingga pada tataran etis suatu tradisi sama baiknya dengan tradisi yang lain. Dengan demikian, suatu tradisi tidak bisa dipadankan dengan tradisi lain. Sementara itu, perspektivisme adalah pandangan yang menilai tradisi hanya dari kerangka tradisinya sendiri, sehingga tradisi yang lain dilihat semata dari perspektif tradisi teretentu. ${ }^{6}$ MacIntyre menilai kedua paham pasca-Pencerahan ini mengandung problematika, karena menolak adanya prinsip objektivitas. Penolakan terhadap prinsip objektivitas membuat etika menjadi tidak mungkin dilaksanakan. Selain itu, penolakan tersebut juga tidak rasional.

\footnotetext{
6 Andy Blunden, "MacIntyre on Justice and Tradition", http://home.mira.net/ andy/works/macintyre.htm - diakses 9 Januari 2013.
} 
MacIntyre kukuh dengan pandangan bahwa rasionalitas mempunyai prinsip objektivitas tertentu.

Akan tetapi, rasionalitas yang dimaksud oleh MacIntyre bukan rasionalitas yang diklaim berlaku universal. Berlawanan dengan paham positivisme yang menyatakan bahwa rasionalitas berdiri secara eksternal dari tradisi, MacIntyre justru mengumumkan bahwa rasionalitas hanya bisa dimengerti dalam batasan suatu tradisi tertentu. Hanya dalam batasan itulah rasionalitas bekerja dan dengan itu pula etika mendapatkan justifikasinya. Masalahnya, menurut MacIntyre, proyek Pencerahan telah menyingkirkan tradisi dan menggantikannya dengan akal budi yang berlaku universal. Tradisi dalam pengertian Pencerahan dianggap irasional, karena hanya bertumpu pada kepercayaan dan otoritas tradisional belaka. Sebaliknya, proyek Pencerahan justru mengandaikan bahwa "ada tolok ukur-tolok ukur rasionalitas yang memadai untuk mengevaluasikan jawaban-jawaban bersaing terhadap pertanyaan-pertanyaan (tentang keadilan dsb.), yang tersedia sama saja, sekurang-kurangnya pada prinsipnya, bagi semua orang dari tradisi mana saja". ${ }^{7}$ Lebih lanjut MacIntyre menjelaskan pengertian proyek Pencerahan sebagai berikut:

Adalah aspirasi sentral Pencerahan ... menyediakan bagi debat dalam wilayah publik tolok ukur-tolok ukur dan metode-metode pembenaran (justification) rasional yang dengannya kemungkinan-kemungkinan bertindak alternatif dalam setiap bidang kehidupan dapat dinilai sebagai adil atau tidak adil, rasional atau tidak rasional, tercerahkan atau tidak tercerahkan. Demikian diharapkan bahwa akal budi akan menggantikan otoritas dan tradisi. Pembenaran rasional harus mengacu pada prinspiprinsip tak terbantah oleh kehususan-kekhususan budaya yang oleh para pemikir Pencerahan dianggap tidak lebih daripada pakaian akal budi kebetulan di waktu dan tempat tertentu. Dan pembenaran rasional tidak dapat lain daripada apa yang menurut para pemikir Pencerahan akan

7 Dikutip dalam Franz Magnis-Suseno, 12 Tokoh Etika Abad ke-20 (Yogyakarta: Kanisius, 2000), 195. 
diterima, sekurang-kurangnya oleh mayoritas besar orang-orang terdidik, dalam tatanan kultural dan sosial pasca-Pencerahan. ${ }^{8}$

Oleh karena itu, MacIntyre berpendapat bahwa sejak awal proyek Pencerahan telah gagal sebagai pendasaran bagi etika. Akan tetapi, seperti disebut di atas, MacIntyre juga tidak setuju dengan pandangan pasca-Pencerahan. Untuk mengatasi problematik etika kontemporer, MacIntyre tidak merujuk baik pada Pencerahan maupun pascaPencerahan, melainkan justru pada etika yang berlaku pada masa praPencerahan. Secara gamblang MacIntyre mengajak kita menengok kembali pandangan etika sebagaimana dibangun oleh Aristotelles dan Thomas Aquinas. Secara historis, yang pertama mengacu pada masa Yunani Kuno, sedangkan yang kedua merujuk pada masa Abad Pertengahan. Etika pra-Pencerahan dalam pandangan MacIntyre justru telah memberikan dasar bagi berlakunya etika karena menunjukkan konsepsi yang jelas dan terarah tentang manusia. Moralitas pada masa itu mempunyai struktur yang membagi secara fundamental antara "manusia-seadanya" (man-as-he-happens-to-be) dan "manusia-yangmungkin-seandainya-ia-merealisasikan-kodrat-hakikinya" (man-as-hecould-be-if-he-realized-his-essential-nature). Dalam pengertian ini, "etika adalah ilmu yang memungkinkan manusia mengerti bagaimana ia dapat melakukan peralihan dari yang pertama ke yang kedua". ${ }^{9}$ Dengan kata lain, hanya dengan merealisasikan potensialitas manusia itulah etika menjadi mungkin dan juga masuk akal.

Pertanyaannya, apakah dengan pandangan demikian MacIntyre sedang mengajak kita untuk kembali ke tradisi yang berlaku pada zaman lampau? Bagaimana mungkin itu dilakukan di tengah zaman kita sekarang yang justru ditandai dengan pluralitas dan bahkan saling

\footnotetext{
$8 \quad$ Ibid., 194.

9 Dikutip dalam Franz Magnis-Suseno, Etika Abad Kedua Puluh: 12 Teks Kunci (Yogyakarta: Kanisius, 2006), 215.
} 
tumpang-tindih tradisi dan identitas? Bagian seterusnya dari tulisan ini akan mencoba menjawab pertanyaan-pertanyaan ini.

\section{Krisis Epistemologis}

Sebelum masuk ke dalam pembahasan tentang rasionalitas tradisi, penting mendiskusikan terlebih dulu apa yang dimaksud MacIntyre dengan krisis epistemologis. Bagi mereka yang tinggal di Indonesia, apalagi mereka yang mengamati secara seksama 'transisi menuju demokrasi' setelah jatuhnya Orde Baru, tampaknya tidak sulit merasakan apa yang dimaksud oleh MacIntyre dengan istilah itu. Dalam kehidupan publik, misalnya, sementara otoriterisme telah senja, obor demokrasi yang berdampak positif bagi kesejahteraan orang banyak belum juga nyala. Dalam kondisi ini, pada rentang yang paling ekstrem muncul pilihan: balik ke masa lalu yang pasti dengan segala plus dan minusnya, atau terus berjalan ke depan dengan memutus sama sekali mata rantai sejarah sebelumnya. Jika dihadapkan pada jenis pilihan ini, cukup pasti MacIntyre akan menolak keduanya. Berpaling tanpa kritis pada sejarah, atau melangkah ke depan tanpa berpijak pada sejarah, sama-sama merupakan pilihan yang tidak etis dan juga tidak rasional.

Dalam sebuah artikel yang dipublikasi pertama kali pada 1977,10 empat tahun sebelum terbit edisi pertama After Virtue, MacIntyre memberikan penjelasan tentang krisis epistemologis dengan mengajukan contoh berikut:

Apakah krisis epistemologis itu? Pertimbangkan, pertama-tama, situasi orang biasa yang terlempar ke dalam krisis tersebut. Seseorang yang telah percaya bahwa dia sangat dihargai oleh majikan dan rekan-rekannya tibatiba dipecat; seseorang yang mengusulkan untuk keanggotaan sebuah klub yang semua anggota-anggotanya, ia percaya, adalah teman-teman dekatnya, ternyata ditolak. Atau seseorang jatuh cinta dan perlu tahu perasaan sesungguhnya dari yang dicintainya; seseorang yang putus cinta dan perlu tahu bagaimana dia bisa keliru dengan yang lain.

\footnotetext{
10 Alasdair MacIntyre, "Epistemological Crises, Dramatic Narrative, and the Philosophy
} of Science" dalam The Monist Vol. 60, No. 4 (1977): 453. 
Dari contoh peristiwa-peristiwa tersebut bisa disarikan bahwa krisis epistemologis adalah situasi peralihan dari apa yang seolah-olah (seems) ke apa yang sesungguhnya terjadi (is). Peralihan tersebut menimbulkan pertanyaan serius, bahkan bagi seorang awam sekalipun, tentang keabsahan cara mendapatkan pengetahuan sebelumnya yang terbukti bertolak belakang dengan kenyataan yang terjadi. Dalam konteks tradisi, MacIntyre menyebut krisis epistemologis adalah sebuah situasi ketika tradisi "yang sejauh itu dipercaya sebagai metode pencarian ternyata telah menjadi steril". ${ }^{11}$ Lebih jelasnya, krisis epistemologis adalah kondisi ketika tradisi tidak lagi mampu memecahkan secara rasional permasalahan-permasalahan yang menimpa dirinya sendiri. Permasalahan yang dimaksud bisa berupa konflik yang sangat tajam di antara dua pandangan moral atau lebih, yang masing-masing berangkat dari pengandaian berbeda, sehingga sangat sulit dicari pemecahan untuk menjembataninya.

Menghadapi krisis epistemologis ini, MacIntyre menggambarkan dua model yang digunakan untuk mengatasinya, yaitu model Hamlet dan Descartes. ${ }^{12}$ Model Hamlet mengacu pada tokoh Hamlet dalam kisah karangan Shakespeare yang terkenal itu. Diceritakan, Hamlet pulang ke kota kelahirannya di Elsinore setelah melakukan perjalanan jauh. Ketika tiba, dia terkejut karena menemukan ayahnya telah terbunuh dan ibunya telah menikah lagi dengan saudara ayahnya alias pamannya sendiri, serta arwah ayahnya yang gentayangan. Saat itu, dia tidak tahu apa yang sesungguhnya terjadi dan kepada siapa dia harus percaya. Tidak hanya itu, dia juga mempertanyakan mengapa dia percaya pada cara dia mengetahui peristiwa yang mengejutkannya itu. Dengan ungkapan lain, narasi dramatis yang menyusun pengetahuan tentang semua hal yang

11 Dikutip dalam Micah Lott, "Self-Contradiction and Self-Reference in Alasdair MacIntyre's Account of Tradition-Based Rationality", Journal of Religious Ethics Vol. 30, No. 3 (2002): 320.

12 MacIntyre, "Epistemological Crises" dalam The Monist 60 no. 4 (1997): 453. 
berkait dengan peristiwa kesejarahan yang sedang dihadapinya tersebut terbantah.

Akan tetapi, segera setelah menghadapi keragu-raguan itu, Hamlet melakukan rekonstruksi naratif untuk menyusun ulang kebenaran yang selama ini ternyata hanyalah seolah-olah. Dia kemudian menciptakan narasi baru yang memungkinkannya mengerti bagaimana dia mengikuti keyakinan yang ternyata tidak sesuai dengan kenyataan dan mengapa dia tertipu dengan itu. Dia tidak meninggalkan narasi sebelumnya, melainkan melampauinya untuk menghasilkan narasi baru yang lebih besar. Akan tetapi, Hamlet percaya bahwa narasi barunya bukanlah kesimpulan final, melainkan penjelasan terbaik yang bisa dihasilkan saat itu. Mungkin di kemudian hari ada cara lain yang bisa mengubahnya.

Sementara itu, model penyelesaian krisis epistemologis ala Descartes bercorak keraguan radikal, bahkan subjek yang sedang mengalami keraguan itu sendiri diragukan sedemikian rupa. Ketika mengalami krisis, Descartes menanggalkan semua pengetahuan dan memulai usaha untuk menemukan pengetahuan baru. Akan tetapi, berbeda dengan Hamlet, cara Descartes memulai pencarian pengetahuannya itu didasarkan sepenuhnya pada nalar yang tidak berpijak pada apapun. Nalar, dengan demikian, diandaikan tidak mempunyai sejarah sama sekali. Bahkan, keraguannya pun disengaja, tidak berangkat dan menuju suatu konteks tertentu.

Dalam pandangan MacIntyre, Descartes tidak konsisten, sebab dia menulis dalam bahasa Perancis dan Latin yang tak lain merupakan suatu tradisi. Seharusnya dia juga meragukan kemampuan dua bahasa tersebut dalam menyampaikan pikirannya, sebab bahasa adalah tradisi melalui apa dunia dilihat dan ditata. Menurut MacIntyre, keraguan Descartes juga merupakan sesuatu yang khas dalam tradisi kedua bahasa itu, yaitu kecenderungan untuk melawankan pengetahuan dengan pengamatan inderawi. Jika sama sekali meragukan kemampuan bahasa dalam menyampaikan pikiran, Descartes dinilai tidak mengetahui sedang 
menanggapi apapun, sebab krisis epistemologis bukanlah krisis sepanjang ruang dan waktu, melainkan tanggapan terhadap situasi khusus.

Oleh karena itu, MacIntyre memilih model Hamlet daripada Descartes, karena baginya rasionalitas tanpa konteks sama dengan rasionalitas tanpa orientasi. Oleh sebab ini, seperti disebut di depan, etika menjadi tidak relevan. Lebih lanjut MacIntyre berpendapat bahwa krisis epistemologis selalu merupakan krisis dalam epistemologi tradisi tertentu, sehingga cara mengatasinya pun mau tak mau harus berangkat dari tradisi itu. Dalam kata-katanya sendiri dikatakan bahwa "tidak ada tanah untuk berdiri, tidak ada tempat untuk penyelidikan, tidak ada jalan untuk terlibat dalam praktik memajukan, mengevaluasi, menerima, dan menolak argument yang masuk nalar selain bahwa itu disediakan oleh beberapa tradisi tertentu atau yang lainnya".13

Pertanyaan kemudian adalah: apakah yang dimaksud tradisi? Secara singkat MacIntyre menulis bahwa tradisi yang dimaksudkannya adalah “... [sesuatu] yang berkembang secara historis, mempunyai argumen yang terwujud secara sosial ...". ${ }^{14}$ Tradisi dengan kriteria semacam ini menyediakan kepada para pengikutnya seperangkat keyakinan tentang dunia, beserta cara untuk mengatasi problemnya. Dengan kata lain, tradisi bagi MacIntyre adalah sebuah argumen rasional yang bekerja berdasarkan historisitas seseorang. Dalam bukunya, dia menjelaskan bagaimana justifikasi rasional dilakukan dalam tradisi Aristotelian, Augustinian, Pencerahan Skotlandia, dan tradisi liberal. Dari telaah terhadap empat tradisi tersebut, muncul problem tentang hubungan antar-tradisi, termasuk kompetisi intra dan antar-tradisi yang akan dibahas nanti di bawah.

13 Dikutip dalam Lott, "Self-Contradiction" dalam Journal of Religious Ethics 30 no. 3 (2002): 316 .

$14 \quad$ Ibid., 317. 
Sebelumnya penting dikemukakan bahwa model penyelesaian krisis epistemologis di atas merupakan tanggapan MacIntyre teradap Thomas Kuhn pada satu sisi dan Imre Lakatos pada sisi lain. ${ }^{15}$ Di sini kita akan menjumpai MacIntyre sebagai seorang filsuf yang ikut serta dalam persoalan filsafat ilmu, agak menjauh dari popularitas MacIntyre sebagai filsuf moral. Kuhn terkenal dengan pendapatnya tentang revolusi keilmuan. Perkembangan ilmu menurut Kuhn terjadi melalui perubahan paradigma yang bersifat revolusioner. Satu paradigma digantikan oleh paradigma yang lain terjadi dalam pengertian yang hampir mistis. Dunia sebelum dan setelah terjadinya perubahan paradigma tidak bercocokan (incompatible) sama sekali, begitu pula dengan dua paradigma di dua dunia tersebut yang tidak bersepadanan (incommensurable) sepenuhnya.

Sementara itu, Imre Lakatos pada mulanya hendak mempertemukan revolusi paradigmanya Kuhn pada satu sisi dan Karl Popper yang lebih melihat perkembangan ilmu sebagai perkembangan yang rasional pada sisi lain. Dalam perkembangannya, Lakatos dinilai justru mengembangkan pemikiran Popper dengan menekankan sejarah ilmu dalam membangun model rasionalitas keilmuan. Dalam hal ini, Lakatos membedakan antara sejarah internal yang bersifat normatif dan sejarah eksternal yang bersifat aktual. Jika rekonstruksi sejarah internal tidak berhasil menjelaskan perkembangan ilmu, rekonstruksi sejarah eksternal diperlukan dengan menggunakan logika penemuan.

MacIntyre menilai apa yang disampaikan oleh Kuhn sama dengan krisis epistemologis yang dialami oleh Descartes. Oleh karena itu, dia menolak revolusi paradigmatik Kuhn karena berimplikasi pada relativisme dan perspektivisme yang hendak dikritisinya. Kalau menggunakaan argumen Kuhn, dialog antartradisi menjadi tidak mungkin. Terhadap Lakatos, MacIntyre juga mengajukan keberatan karena rekonstruksi rasional yang diusulkannya tak lebih dari

15 MacIntyre, "Epistemological Crises" dalam The Monist 60 no. 4 (1997). 
metafisika, jadi bukan sejarah konkret dalam pengertian MacIntyre. Selain itu, bagi MacIntyre, sejarah aktualnya Lakatos terlihat hanya merupakan usaha yang dicocok-cocokkan dengan sejarah internal yang menjadi inti program riset sainsnya. Meski demikian, pengamat seperti Robert Miner berpendapat bahwa MacIntyre dan Lakatos adalah dua pemikir yang bisa saling melengkapi, terutama dalam rangka mengatasi problem ketidaksepadanan (incommensurability) yang dikemukakan oleh Kuhn. ${ }^{16}$

\section{Rekonstruksi Naratif}

Dengan mengajak kita untuk menoleh kepada etika praPencerahan, MacIntyre sedang mengembalikan etika kembali ke keutamaan. Sejak Pencerahan, etika keutamaan yang bertanya "aku hendaknya menjadi manusia macam apa" dikubur dan digantikan oleh etika modern yang terutama mengacu pada etika deontologis Kant, utilitarisme, dan hedonisme. Secara singkat, berkait dengan tema keadilan, misalnya, ketiga jenis etika modern itu mengajukan argumen berikut: (1) "karena itu kewajibanmu" (Kant); (2) "karena keadilan menghasilkan kebahagiaan maksimal sebanyak mungkin orang" (etika teleologis, utilitarisme); dan (3) "karena bertindak dengan adil memberikan paling banyak nikmat" (hedonisme). ${ }^{17}$ Dari sini terlihat bahwa etika modern tidak menyediakan kerangka teleologis sama sekali, sehingga apa yang hendak dituju oleh manusia dikembalikan sepenuhnya kepada "kehendak" manusia itu sendiri. Sambil merujuk pada Nietzsche, MacIntyre menyebut etika modern bersifat nihilistik.

Nihilisme yang menguasai paham etika modern dinilai oleh MacIntyre berakhir pada jalan buntu. Etika modern gagal dalam menjawab persoalan etis yang berangkat dari argumen yang berbeda.

16 Robert Miner, "Lakatos and MacIntyre on Incommensurability and the Rationality of Theory-change", http://www.bu.edu/wcp/Papers/Scie/ScieMine.htm - diakses 8 Januari 2013.

17 Magnis-Suseno, 12 Tokoh, 195. 
Dengan ungkapan lain dikatakan bahwa etika modern tidak mempunyai kriteria mendasar untuk memutuskan pertentangan di antara prinsipprinsip yang bertolak belakang. Akibatnya, konflik pandangan mengenai kasus etis tertentu tidak bisa diatasi, sebab rasionalitas yang menjadi satu-satunya kriteria dalam kenyataannya tidak berlaku secara universal. Rasionalitas antara manusia satu dan manusia lainnya berdiri sendiri mengikuti kehendak tuannya yang berbeda-beda.

Oleh karena itu, salah satu konsep penting dalam etika MacIntyre adalah "tatanan naratif kehidupan seseorang" (narrative order of a single human life). ${ }^{18}$ Melalui tatanan inilah manusia ditempatkan dalam kehidupan bersama. Di sini kelihatan sekali posisi MacIntyre sebagai seorang komunitarian. "Kegiatan bermakna" (practice) seseorang hanya dimengerti dalam tatanan naratif tertentu yang tak lain adalah tradisi yang di dalamnya seseorang hidup dan berinteraksi dengan orang lain. Dalam konteks ini pula "keutamaan" (virtue) memperoleh maknanya. Sumbernya bisa berasal dari kepercayaan metafisik seperti pada Aristotelles, tetapi bisa juga berasal dari iman seperti pada Aquinas. Intinya, keutamaan akan bekerja dalam tradisi yang mempunyai orientasi tentang telos manusia. Masalahnya, dalam tradisi Barat modern, istilah "virtue" memang lebih dimengerti sebagai kesalehan, meskipun sejatinya ia bermakna lebih luas daripada itu - berasal dari kata "arete" dalam tradisi Yunani kuno. Oleh karena itu, terjemahan bahasa Indonesia untuk istilah "virtue", yaitu keutamaan, terasa lebih pas. Keutamaan mempunyai makna yang lebih bernuansa daripada kesalehan.

\section{Mengkompetisikan Tradisi}

Setelah menguraikan pemikirannya tentang rasionalitas-terikattradisi, muncul pertanyaan terhadap MacIntyre: bagaimana menjustifikasi rasionalitas-terikat-tradisi itu? Lalu apakah suatu tradisi

18 Ibid., 200. 
bisa dipadankan dalam suatu kompetisi rasional dengan tradisi lain? Dalam konteks kita di Indonesia akhir-akhir ini, pertanyaan-pertanyaan ini sungguh relevan ketika menyaksikan kenyataan mengenai banyaknya ketegangan antar-tradisi, persis setelah klaim kebenaran yang sebelumnya digenggam oleh negara secara sentralistis runtuh. Dalam banyak peristiwa muncul perseteruan antara kaum relijius dan kaum sekuler - keduanya adalah tradisi dalam pengertian MacIntyrian mengenai peraturan publik dan banyak isu lainnya. Apakah gagasan MacIntyre bisa sedikit mengurai benang kusut ini?

Di atas telah disinggung bahwa menurut MacIntyre tradisi bisa berkembang dan bahkan berkompetisi secara rasional, baik dalam dirinya sendiri maupun dengan tradisi lain. Untuk sampai pada kompetisi rasional itu, tradisi melewati beberapa tahap. Dimulai dengan tahap ketika otoritasnya terterima, suatu tradisi kemudian naik satu tahap di mana ketidakmemadaian dalam keyakinan yang terterima itu teridentifikasi tetapi tidak teratasi. Setelah itu, suatu tradisi masuk ke tahap selanjutnya dalam apa "tanggapan terhadap ketidakmemadaian tersebut menghasilkan seperangkat reformulasi, reevaluasi, dan formulasi serta evaluasi baru, yang dirancang untuk memperbaiki ketidakmemadaian dan untuk mengatasi keterbatasan". ${ }^{19}$ Pada tahap ini para pengikut suatu tradisi berada pada posisi untuk mengakui kesenjangan antara dunia yang mereka pahami sekarang dengan dunia yang mereka yakini sebelumnya. Dalam posisi ini, tradisi sebelunya dinilai 'palsu', sehingga harus disusun tradisi baru yang 'benar'. Mengenai tahap-tahap pencarian rasionalitas tradisi ini, MacIntyre menjelaskan:

Rasionalitas terbentuk tradisi adalah bagian penting dari jenis kemajuan yang dibuat melalui sejumlah tahap yang terdefinisi dengan baik. Setiap bentuk pencarian rasionalitas tersebut dimulai dalam dan dari beberapa

19 Dikutip dalam Lott, "Self-Contradiction” dalam Journal of Religious Ethics 30 no. 3 (2002): 319 . 
kondisi kontingensi sejarah murni, dari keyakinan, institusi, dan kegiatan bermakna yang membentuk beberapa komunitas tertentu ${ }^{20}$

Dalam penjelasan mengenai tahap-tahap di atas, terlihat MacIntyre sedang menggunakan logika dialektis. Di sini kelihatan MacIntyre adalah seorang Hegelian. Tujuan dari proses dialektika tradisi adalah pencapaian keyakinan yang benar, yaitu keyakinan yang tidak lagi mengidap ketidakmemadaian seperti dalam keyakinan sebelumnya. Kemampuan untuk bertahan dalam proses dialektis ini adalah kriteria untuk menjustifikasi klaim-klaim tradisi. Akan tetapi, sekali lagi ditekankan bahwa proses dialektis itu sendiri terselenggara di dalam tradisi itu sendiri. Oleh karena itu, historisitas menjadi sangat penting.

Masalahnya, sangat terbuka kemungkinan sebuah tradisi tidak mampu mengatasi krisis epistemologis yang terjadi dalam dirinya. Dalam situasi ini, pengikut tradisi bersangkutan mau tak mau berpaling untuk berdialog dengan tradisi lainnya. Akan tetapi, MacIntyre mengingatkan bahwa hal itu tidak mudah, sebab mereka yang masuk ke dalam tradisi lain di luar tradisinya sama dengan belajar "bahasa pertama kedua" ("second first languange"). Dengan kata lain, mereka harus melihat tradisi lain dengan perspektif yang dimiliki oleh tradisi itu, tidak bisa menggunakan perspektif tradisinya sendiri. Di sinilah pentingnya semacam hermeneutika yang digunakan untuk meneropong, atau paling tidak mengimajinasikan, tradisi di luar tradisi aslinya. Tanpa itu, usaha dialog akan terjatuh pada perspektivisme atau etnosentrisme kalau menggunakan istilah dalam ilmu-ilmu sosial dan kebudayaan. Hanya dengan memahami kedua bahasa tradisi secara baik, krisis epistemologis bisa dicari jalan keluarnya dengan menggunakan dua narasi secara bersamaan.

\footnotetext{
20 Dikutip dalam Jean Porter, "Tradition in the Recent Work of Alasdair MacIntyre", dalam Mark C. Murphy (ed.), Alasdair MacIntyre (New York: Cambridge University Press, 2003), 46.
} 
Sekarang cukup jelas bagi kita bahwa kriteria yang bernilai objektif tetap dipertahankan dalam rasionalitas-terikat-tradisinya MacIntyre. Hanya dengan itulah tradisi menjadi rasional. Sebaliknya, tanpa adanya kriteria tertentu, tradisi-tradisi akan tergelincir pada relativisme, sehingga hanya bermonolog dengan dirinya sendiri. Dalam konteks ini, liberalisme sebagai sebuah tradisi dikritik oleh MacIntyre karena klaim universal dan orientasi individual di dalam dirinya. Individualisme liberal bagi MacIntyre tidak bisa menjadi basis rasionalitas dan etika, sebab ia tidak mempunyai tempat dan ruang yang spesifik.

\section{Penutup}

Gagasan MacIntyre tentang rasionalitas dan etika telah memberikan sumbangan penting bagi filsafat dan ilmu-ilmu sosial humaniora. MacIntyre adalah bagian dari para pemikir komunitarian yang berpandangan bahwa cara hidup liberal yang individualistik gagal dalam mengatasi problem moral yang menimpanya. Mereka terutama mengarahkan kritiknya pada kapitalisme kontemporer yang dinilai merusak keutamaan moral sebagaimana terbangun secara apik dalam komunitas-komunitas tradisi. MacIntyre secara spesifik merujuk contoh pengalaman berkomunitas pada masa Yunani Kuno dan Abad Pertengahan seperti dirumuskan oleh Aristotelles dan Thomas Aquinas yang mengintegrasikan etika dan politik dalam praktik sosial sehari-hari.

Akan tetapi, apakah model berkomunitas yang dibayangkan oleh MacIntyre tersebut bisa diterapkan di dunia kita sekarang yang sangat kompleks, itu adalah pertanyaan yang perlu didiskusikan lebih lanjut. Selain itu, belakangan juga semakin disadari bahwa seseorang seringkali tumbuh kembang dalam pluralitas tradisi yang tidak jarang bersifat tumpang tindih. Saya sendiri, misalnya, adalah seorang Sunda, Indonesia, Muslim, dan tinggal di Jakarta yang cukup kosmopolit. Seperti dikatakan oleh MacIntyre, masing-masing tradisi tersebut memang mempunyai "bahasa" yang mau tidak mau harus dipelajari secara seksama. Akan tetapi, menyebut bahasa-bahasa tersebut sebagai 
"bahasa pertama kedua" tampaknya juga perlu ditinjau lagi, mengingat kuatnya pengaruh modernisasi, misalnya di sekolah dan universitas, yang membuat batas-batas antara tradisi tersebut tidak sekokoh seperti pada masa sebelumnya.

Meski demikian, di tengah era kebangkitan politik identitas sekarang ini, argumen MacIntyre yang tetap mempertahankan sebuah kriteria (atau meta-kriteria) objektif dalam proses justifikasi tradisi, sangat relevan. Di Indonesia akhir-akhir ini terlihat sekali tradisi-tradisi mengartikulasikan diri secara bebas hingga ke batas-batas yang justru mengancam kebebasan itu sendiri. Yang paling mutakhir adalah munculnya wacana mengenai "pribumi". Dalam sambutannya ketika dilantik menjadi Gubernur DKI Jakarta 2017-2002, Anies Baswedan mengatakan bahwa sekarang adalah saatnya kaum pribumi berkuasa. Reaksi pun bermunculan karena istilah tersebut tentu saja merujuk pada sosok gubernur sebelumnya yang berasal dari kalangan keturunan Tionghoa. Oleh karena itu, tidak sedikit kalangan yang bahkan selama ini disebut pribumi pun merasa keberatan. Mereka melihat ada "krisis epistemologis" dalam istilah itu, mengingat pribumi pada dasarnya adalah konsep yang lahir dari konteks kolonial yang sarat dengan kepentingan. Jika kerangka yang disediakan oleh MacIntyre digunakan dalam kontroversi ini, maka seharusnya konsep pribumi dikompetisikan secara rasional terlebih dahulu. Dengan demikian, ia tidak secara otomatis merujuk pada etnis tertentu, selain ia juga bisa tidak dipakai lagi jika tradisi-tradisi yang ada sekarang karena alasan objektif tertentu, katakanlah integrasi bangsa, tidak menghendakinya. 